\title{
Holothuria leucospilota Population in Satang Besar Island, Sarawak, Malaysia
}

\author{
Mohd Nasarudin Harith ${ }^{D},{ }^{1}$ Muhammad Hasanol Isyraf Md Desa, ${ }^{1}$ and Zaidnuddin Ilias ${ }^{2}$ \\ ${ }^{1}$ Aquatic Resource Science and Management Programme, Faculty of Resource Science and Technology, \\ Universiti Malaysia Sarawak, 94300 Kota Samarahan, Sarawak, Malaysia \\ ${ }^{2}$ Marine Culture Research Division, Fisheries Research Institute Langkawi, Bukit Malut, 07000 Langkawi, Kedah, Malaysia
}

Correspondence should be addressed to Mohd Nasarudin Harith; hmnasarudin@unimas.my

Received 29 March 2018; Revised 9 July 2018; Accepted 14 July 2018; Published 5 August 2018

Academic Editor: Marco Cucco

Copyright (C) 2018 Mohd Nasarudin Harith et al. This is an open access article distributed under the Creative Commons Attribution License, which permits unrestricted use, distribution, and reproduction in any medium, provided the original work is properly cited.

Holothuria leucospilota or locally known as "Patola" is currently considered the most abundant sea cucumber species in Malaysia. This coral reef-dwelling species is not in danger of extinction in comparison to commercial sea cucumbers such as "gamat." However, overfishing activities in addition to lack of fishing regulations in Malaysia could put this species at risk of extinction in the future. It is important to conduct research on the sea cucumber community in Sarawak because the data can be used as reliable information for future research. Therefore, this study is carried out to quantify and estimate the Holothuria leucospilota population from an intertidal area of Satang Besar Island, Sarawak, Malaysia. Ten stations surrounding the island were selected as the location for this study. A total number of 203 individuals of Holothuria leucospilota were recorded and estimation of the population that inhabits the island's intertidal area was 609 individuals. RELATE test showed relationships between species population and water parameters, namely, temperature, salinity, and $\mathrm{pH}$. Results from this study are important as a baseline data that might contribute to the sustainable management of Sarawak, Malaysia's sea cucumber in the future. Future work suggestions include addition of subtidal samples and other factors, namely, seawater nutrients and feeding environment, that should be done to better understand the population.

\section{Introduction}

Holothuria leucospilota or locally known as Patola or bat puntil is currently considered as the most abundant sea cucumber species in Malaysia [1]. This species is usually found in coral reefs' sandy area. This species is tolerant to air exposure over a long period of time and might be found in the area closest to the coast [2]. This species can be found inhabiting the coastal areas of subtropical and tropical oceans [3]. Holothuria leucospilota is commonly found at the edge of reef flat shore in the intertidal area, where it occupies tidal pool with the depths ranging from several centimetres to a half metre or being fully exposed [4]. The posterior body of Holothuria leucospilota possesses the capability of extension from under rock or a hole in the reef floor where it anchors for feeding [5].

Morphologically, Holothuria leucospilota has uniformly black colour body. It is soft-bodied and equipped with fine protuberances. This species has shield-shaped tentacles which are placed under the order of Aspidochirotida from the family of Holothuriidae. To further confirm the species identity, ossicle shape from dorsal cuticles of the sample was observed.

This coral reef-dwelling species is not in danger of extinction like the commercial Stichopus species such as Stichopus horrens that are locally known as gamat [2]. However, due to their widespread and high economic value [6], sea cucumbers in many countries are overfished due to the ease by which sea cucumbers can be collected from shallow reef flats during low tide [7]. Global exploitation of sea cucumbers to meet consumer demand is motivating a rising conservation concern [8-11]. Most tropical sea cucumber fisheries have come under intense fishing pressure in China due to growing human populations that lead to the increase in the demand of sea cucumber product [12]. Moreover, Holothuria leucospilota is 


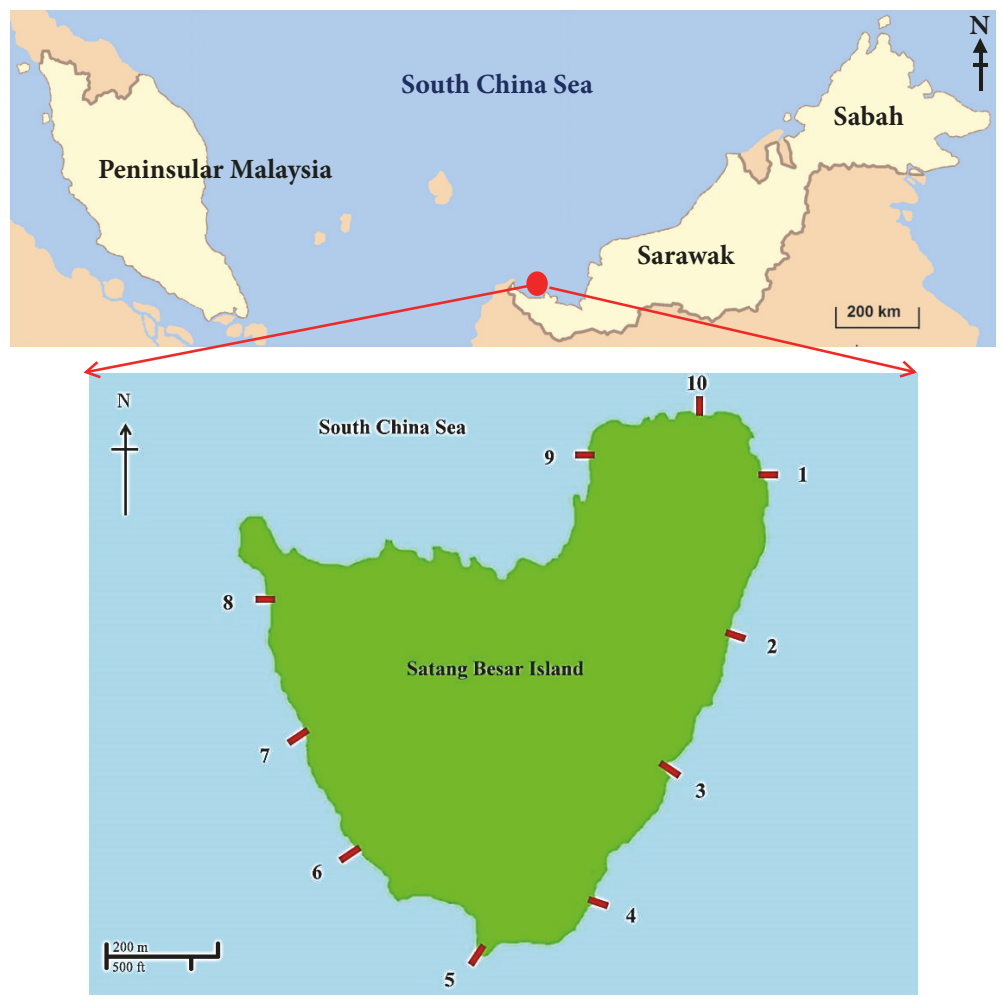

FIGURE 1: A map of Malaysia showing the location of Sarawak and the 10 sampling sites of Satang Besar Island.

listed as one of the edible species with functional ingredients in medicinal sector and also has low toxic effect [13]. The lack of fishing regulations in Malaysia such as the minimum legal permitted size for harvesting, closed season, and catch quota are potentially putting this species on threat in the future.

Therefore, it is important to conduct research for the sea cucumber community in Sarawak because the data can be used as reliable information for future research. The information about sea cucumber population and aquatic ecosystem is essential for commercial use and conservation. The objective of this study is to quantify the population of Holothuria leucospilota sea cucumber from intertidal area of Satang Besar Island, Sarawak, Malaysia.

\section{Materials and Methods}

2.1. Study Site. This study was conducted at the intertidal zone of Satang Besar Island, Sarawak. Satang Besar Island is situated in Talang-Satang National Park (Figure 1). TalangSatang National Park covers 19,414 hectares and was gazetted in 1999 to develop marine turtle conservation in Sarawak [14]. The boat ride to the park takes 30 minutes from Damai Beach, Sarawak Boat Jetty Club, or Telaga Air Jetty. A total number of 10 stations were selected (Table 1). Global Positioning System (GPS) was used to record the location of each sampling station [1]. The sampling stations covered the intertidal area of Satang Besar Island.

2.2. Sample Collection. Figure 2 illustrated the line transect of $100 \mathrm{~m}$ used in each station [15]. Three quadrats measuring
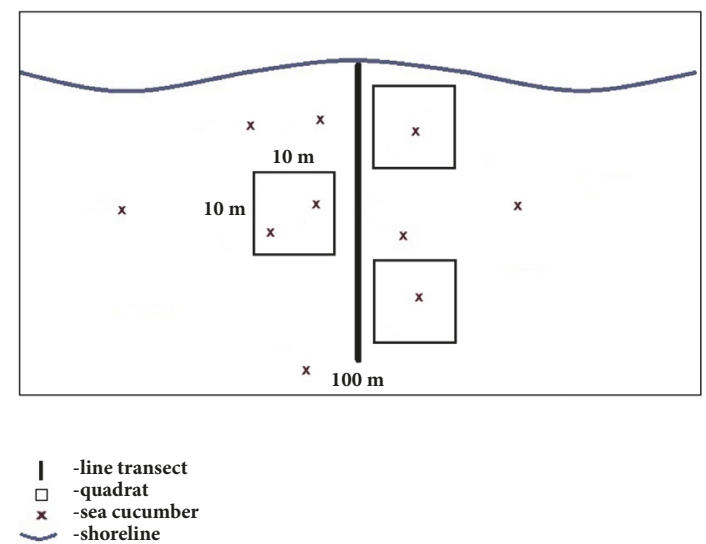

FIgURE 2: Illustration of sampling plan.

$10 \mathrm{~m} \times 10 \mathrm{~m}$ were placed randomly along the transect line. Sea cucumbers found within the quadrat were counted, photographed, and identified. Basic physicochemical parameters, namely, temperature and $\mathrm{pH}$, were also measured during sampling using HANNA Instruments (Model HI9146), while salinity was measured using hand refractometer (Model Milwaukee-MA887).

2.3. Storage and Preservation. Fresh specimens of sea cucumbers collected were stored in ice boxes containing seawater during sampling period. In the laboratories, specimens were 
TABLE 1: Coordinates of sampling stations with their habitat description.

\begin{tabular}{|c|c|c|}
\hline Station & GPS Coordinate & Description \\
\hline \multirow{2}{*}{1} & $\mathrm{~N} 01^{\circ} 47^{\prime} 17.4^{\prime \prime}$ & \multirow{2}{*}{ Large rocky shore with intertidal zone of $39 \mathrm{~m}$} \\
\hline & E $110^{\circ} 09^{\prime} 54.1^{\prime \prime}$ & \\
\hline \multirow{2}{*}{2} & $\mathrm{~N} 01^{\circ} 47^{\prime} 23^{\prime \prime}$ & \multirow{2}{*}{ Medium rocky shore with intertidal zone of $48 \mathrm{~m}$} \\
\hline & $\mathrm{E} 110^{\circ} 09^{\prime} 50.3^{\prime \prime}$ & \\
\hline \multirow{2}{*}{3} & $\mathrm{~N} 01^{\circ} 46^{\prime} 59.9^{\prime \prime}$ & \multirow{2}{*}{ Medium to small rocky shore with intertidal zone of $75 \mathrm{~m}$} \\
\hline & E $110^{\circ} 09^{\prime} 48.4^{\prime \prime}$ & \\
\hline \multirow{2}{*}{4} & $\mathrm{~N} 01^{\circ} 46^{\prime} 56.7^{\prime \prime}$ & \multirow{2}{*}{ Medium to small rocky shore with intertidal zone of $68 \mathrm{~m}$} \\
\hline & $\mathrm{E} 110^{\circ} 09^{\prime} 46.2^{\prime \prime}$ & \\
\hline \multirow{2}{*}{5} & $\mathrm{~N} 01^{\circ} 46^{\prime} 53.7^{\prime \prime}$ & \multirow{2}{*}{ Medium to small rocky shore with intertidal zone of $114 \mathrm{~m}$} \\
\hline & $\mathrm{E} 110^{\circ} 09^{\prime} 44.0^{\prime \prime}$ & \\
\hline \multirow{2}{*}{6} & $\mathrm{~N} 01^{\circ} 46^{\prime} 49.8^{\prime \prime}$ & \multirow{2}{*}{ Medium to small rocky shore with intertidal zone of $84 \mathrm{~m}$} \\
\hline & $\mathrm{E} 110^{\circ} 09^{\prime} 37.1^{\prime \prime}$ & \\
\hline \multirow{2}{*}{7} & 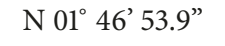 & \multirow{2}{*}{ Medium to small rocky shore with intertidal zone of $63 \mathrm{~m}$} \\
\hline & $\mathrm{E} 110^{\circ} 09^{\prime} 23.6^{\prime \prime}$ & \\
\hline \multirow{2}{*}{8} & $\mathrm{~N} 01^{\circ} 46^{\prime} 55.6^{\prime \prime}$ & \multirow{2}{*}{ Medium to small rocky shore with intertidal zone of $32 \mathrm{~m}$} \\
\hline & $\mathrm{E} 110^{\circ} 09^{\prime} 21.8^{\prime \prime}$ & \\
\hline \multirow{2}{*}{9} & $\mathrm{~N} 01^{\circ} 47^{\prime} 3.2^{\prime \prime}$ & \multirow{2}{*}{ Large rocky shore with intertidal zone of $30 \mathrm{~m}$} \\
\hline & $\mathrm{E} 110^{\circ} 09^{\prime} 13.8^{\prime \prime}$ & \\
\hline \multirow{2}{*}{10} & $\mathrm{~N} 01^{\circ} 45^{\prime} 17.0^{\prime \prime}$ & \multirow{2}{*}{ Large rocky shore with intertidal zone of $34 \mathrm{~m}$} \\
\hline & E $110^{\circ} 09^{\prime} 34.2^{\prime \prime}$ & \\
\hline
\end{tabular}

transferred into $-20^{\circ} \mathrm{C}$ fridge freezer for storage and preserved in $70 \%$ ethanol [1].

2.4. Identification. Identification was based on the external morphology such as body shape and body colour and the existence of tube feet and tentacles. It was done by referring to previous studies by Conand [16], James [17], Kamarudin et al. [1], and Iliyas [2].

2.5. Estimation of Population. Estimation of population can be determined from collected data such as the size of study area, size of quadrat, and the number of sea cucumbers per quadrat [15]. Estimated population size for every station was determined using the following formula:

$$
\mathrm{N}=\left(\frac{\mathrm{A}}{\mathrm{a}}\right) \times \mathrm{n}
$$

where $\mathrm{N}$ is the estimated total population size. A is the total study area. $\mathrm{a}$ is the area of the quadrat. $\mathrm{n}$ is the mean number of sea cucumber per quadrat.

2.6. Species Density. Density of sea cucumber was determined from collected data such as the total number of individuals and the total area sampled [18]. Species density of sea cucumber for every station was determined using the formula below:

$$
\mathrm{D}=\frac{\mathrm{n}}{\mathrm{A}}
$$

where $\mathrm{D}$ is density. $\mathrm{n}$ is total number of individuals of the species. A is total area sampled.
2.7. Statistical Analysis. Variances of sea cucumber abundance, $\mathrm{pH}$, salinity, and water temperature between stations were tested with one-way analysis of variance (ANOVA), using PASW Statistics 18. Significant results $(\mathrm{p}<0.05)$ were obtained and followed with a Tukey post hoc multiple range test [19].

A simple RELATE test was also conducted to determine the relationship between species abundance and abiotic parameters. RELATE is the equivalent of a nonparametric Mantel test [20]; it assesses the degree of correspondence between matrices, and, via a randomization test, it provides a measure of statistical significance of the relationship [21]: the matrix of similarities between species abundances was compared with a matrix of the similarity between abiotic parameters. The significance of any correlation between matrices is assessed with a randomization test. This test was carried out using PRIMER 7 (V7.0.13).

\section{Results and Discussion}

3.1. Density of Holothuria leucospilota. A total of 203 Holothuria leucospilota have been enumerated from an intertidal area of Satang Besar Island (Figure 3). The highest density was from Station 7 with 2.6 individuals found in every $1 \mathrm{~m}^{2}$ (Figure 4). This is because most of the sea cucumber species search for shelter from wave action [22] and rocky shore is the preferable habitat besides coral reefs. The abundance of sea cucumber could be related to the type of food supply availability [23]. There was no sea cucumber found in Stations 1, 9, and 10. This is possibly due to high wave action where Stations 9 and 10 were located. There was 


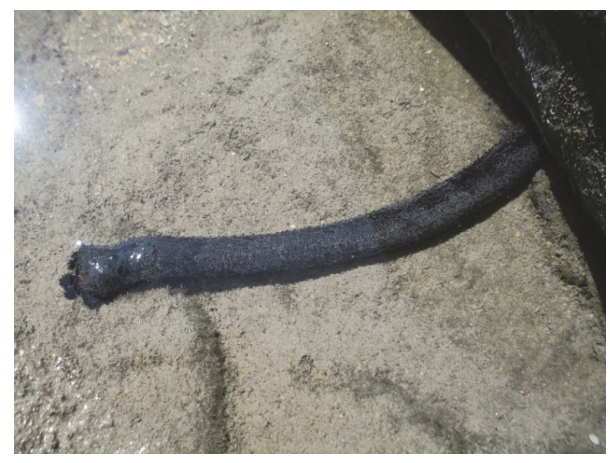

Figure 3: Holothuria leucospilota found from an intertidal area of Satang Besar Island.

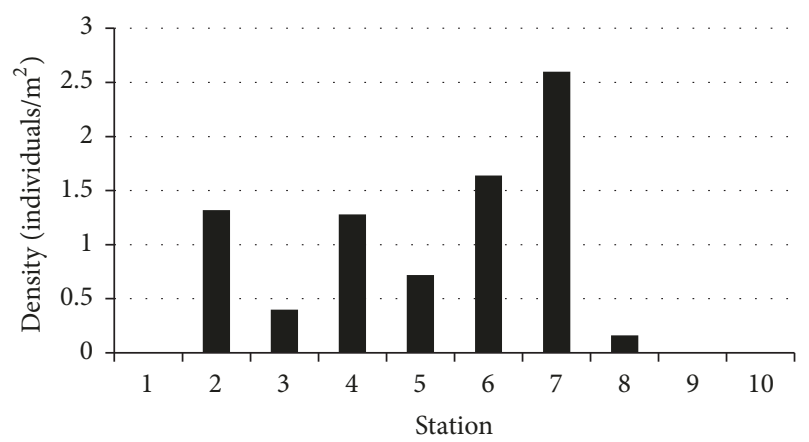

FIgURE 4: Density of Holothuria leucospilota by station.

no sea cucumber found in Station 1 which was characterized by large rocks but lack of seawater (Figure 4 ).

3.2. Population Estimate of Holothuria leucospilota. Overall,

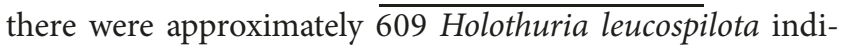
viduals from this survey. The population estimate was conducted according to sampling stations that were set up which were located at the intertidal area. This estimation was also based on the collected data of the total area of each station $\left(150 \mathrm{~m}^{2}\right)$, the size of quadrat $\left(25 \mathrm{~m}^{2}\right)$, and the number of sea cucumbers counted for each station. The estimation of population was not calculated from Stations 1, 9, and 10 since there were no sea cucumbers found (Figure 5).

Estimation of population by population surveys cannot reveal abundance of broad areas. Most of the estimation of population and abundance will be calculated using integrated data with Geographical Information Systems (GIS); however, this method can be costly and access to the technology is limited [24].

3.3. Water Quality Parameters. Water temperature readings from all stations ranged from $27.2^{\circ} \mathrm{C}$ to $40.8^{\circ} \mathrm{C}$. The highest temperature was from Station 6 with $40.77^{\circ} \mathrm{C}$ while Station 10 had the lowest temperature with $27.2^{\circ} \mathrm{C}$ (Figure 6). One-way ANOVA statistical analysis showed that there was significant difference in the value of temperature in all stations (Tukey Test, $\mathrm{p}<0.05)$.

The highest number of sea cucumbers was found in Station 7 has the second highest temperature reading range

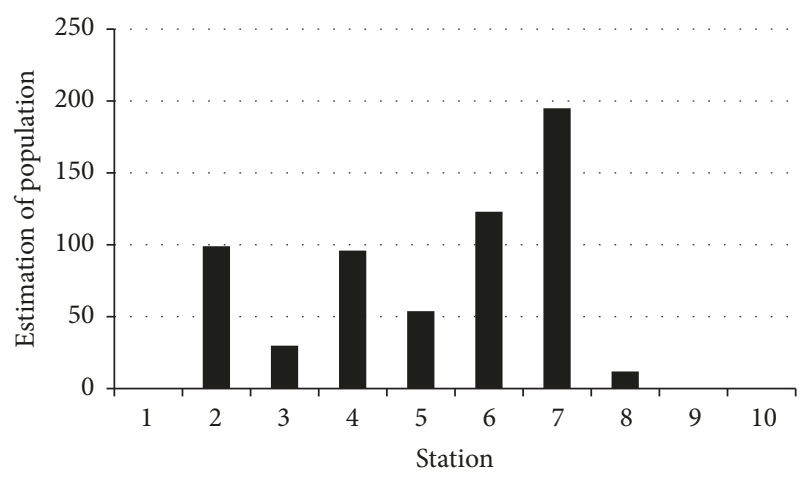

FIGURE 5: Population estimate of Holothuria leucospilota from every station.

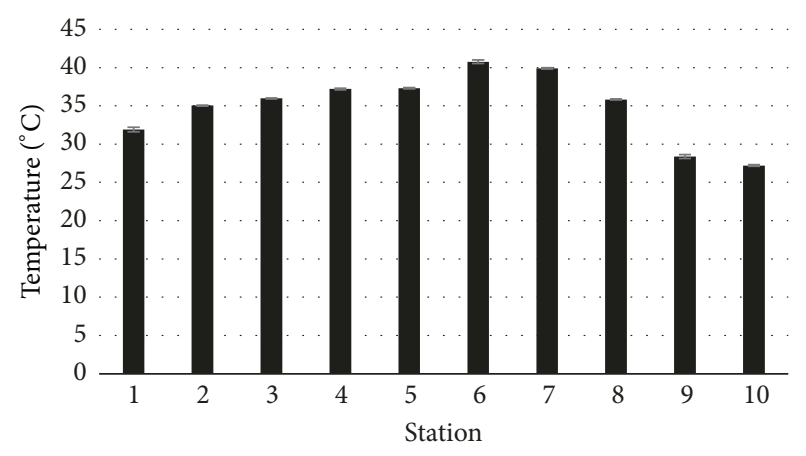

FIgURE 6: Mean temperature from every station.

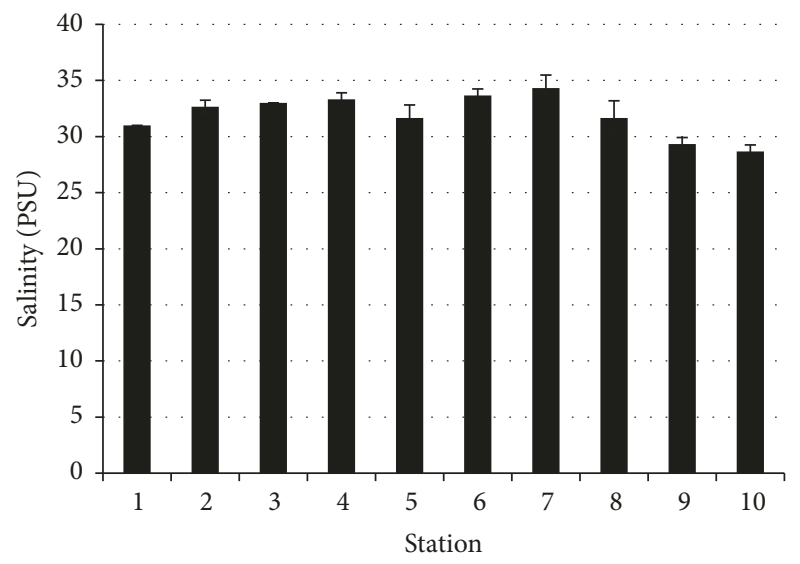

FIGURE 7: Mean salinity from every station.

from $39^{\circ} \mathrm{C}$ to $40^{\circ} \mathrm{C}$. The optimal temperature for Holothuria leucospilota differs from FAO Corporate Document Repository [25] which stated that $5^{\circ} \mathrm{C}$ to $15^{\circ} \mathrm{C}$ is the optimal temperature. The difference may be due to the difference of geographical locations where the sea cucumber was recorded [15].

Salinity for all sampling stations was recorded in the range of 28.67 to 34.33 PSU. The highest salinity was recorded in Station 7 with salinity value of 34.33 PSU (Figure 7). The lowest salinity was recorded in Station 10 with salinity value of 28.67 PSU. One-way ANOVA statistical analysis indicated that there was significant difference in salinity value of all 


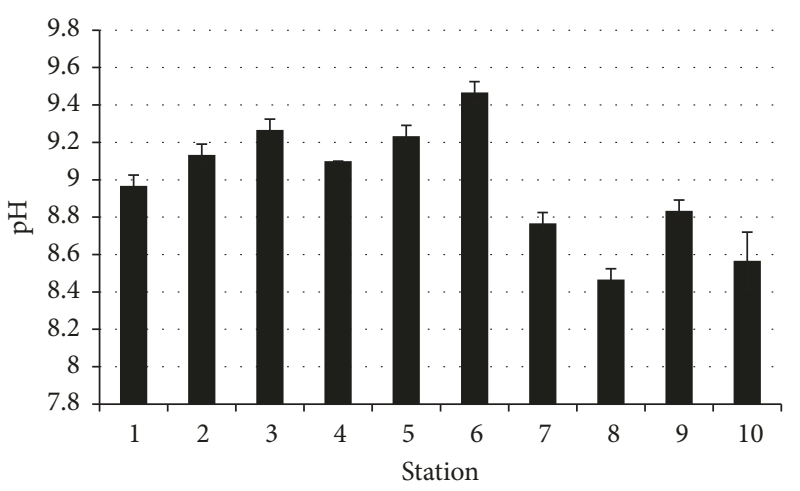

FIGURE 8: Mean pH from every station.

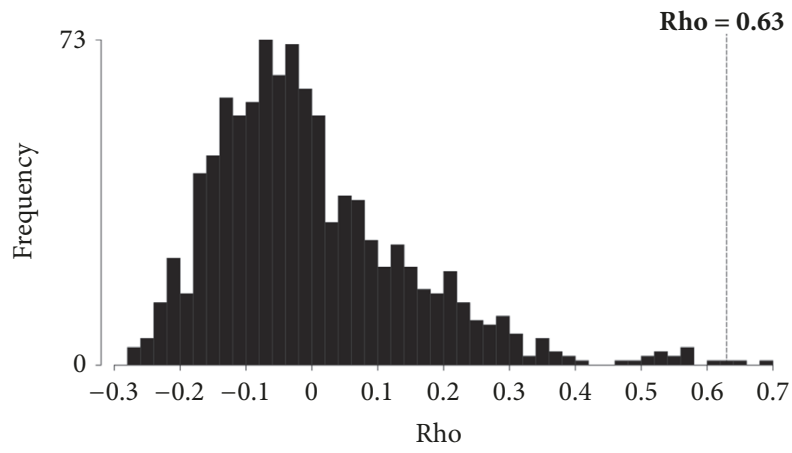

FIGURE 9: RELATE test to observe significant relationship between Holothuria leucospilota community and environmental data. The histograms are the null permutation distributions of possible values for the RELATE match (Spearman $\rho$ s), in the absence of a biota-environment relationship. The observed $\rho \mathrm{s}=0.63$ which is indicated by the dotted line on the right showed presence of the biota-environment relationship as the line is located outside the histograms.

stations (Tukey Test, $\mathrm{p}<0.05$ ). This implies that salinity in Satang Besar Island is favorable for Holothuria leucospilota where salinity ranged from 27 to 35 PSU as its optimum ranges [15].

Water $\mathrm{pH}$ range from 8.47 to 9.47 was recorded throughout all stations. The highest $\mathrm{pH}$ was recorded in Station 6 with $\mathrm{pH}$ measured at 9.47 while the lowest $\mathrm{pH}$ was recorded in Station 8 with $\mathrm{pH}$ measured at 8.47 (Figure 8). One-way ANOVA statistical analysis showed that there was significant difference of $\mathrm{pH}$ value in all stations (Tukey Test, $\mathrm{p}<0.05$ ).

3.4. Relationship between Holothuria leucospilota Abundance and Abiotic Parameters. The results of RELATE tests indicated that there is a correlation between Holothuria leucospilota abundance and physicochemical parameters, namely, temperature, salinity, and $\mathrm{pH}$ (Spearman rank correlation statistic, Rho $=0.63$ ) (Figure 9). Two of the 999 random permutations resulted in a correlation equal to or greater than the measured value of 0.63 , indicating that the correlation was significant at the 0.05 level.

\section{Conclusion}

A total number of 203 individuals of Holothuria leucospilota were recorded from an intertidal area of Satang Besar Island, Sarawak, and the estimation of population that inhabits Satang Besar Island intertidal area was 609 individuals. Most of the population were found at rocky shores which are sheltered from strong waves. Based on the RELATE test, there are significant relationships between the species population and water parameters, namely, temperature, salinity, and $\mathrm{pH}$.

Further study with inclusion of samples from subtidal area and other factors that influence this species population including seawater nutrients and feeding biology could be conducted.

\section{Data Availability}

The data used to support the findings of this study are available from the corresponding author upon request.

\section{Conflicts of Interest}

The authors declare no conflicts of interest.

\section{Acknowledgments}

This research is supported by UNIMAS in terms of transportation and lab facilities. This study would have also been impossible without the unconditional assistance from FRST staffs especially Mr. Zaidi Ibrahim, Mr. Mohamad Norazlan Bujang Belly, and Mr. Richard Toh during field work. Our appreciation also goes to Sarawak Forestry Department for Research Permit NCCD.907.4.4(Jld.VI)-179.

\section{References}

[1] K. R. Kamarudin, A. M. Rehan, A. L. Lukman et al., "Coral reef sea cucumbers in Malaysia," Malaysian Journal of Science, vol. 28, no. 2, pp. 171-186, 2009.

[2] Z. Iliyas, Gamat perairan Malaysia: kepelbagaian spesies dan kegunaannya, Dewan, Bahasa dan Pustaka: Kuala Lumpur, 2010.

[3] Z. Yu, C. Hu, Y. Zhou, H. Li, and P. Peng, "Survival and growth of the sea cucumber Holothuria leucospilota Brandt: A comparison between suspended and bottom cultures in a subtropical fish farm during summer," Aquaculture Research, vol. 44, no. 1, pp. 114-124, 2013.

[4] N. A. Sloan, "Microhabitat and resource utilization in cryptic rocky intertidal echinoderms at Aldabra Atoll, Seychelles," Marine Biology, vol. 54, no. 3, pp. 269-279, 1979.

[5] K. Bonham and E. E. Held, "Ecological observations on the sea cucumbers Holothuria atra and H. leucospilota at Rongelap Atoll, Marshall Islands," Pacific Science, vol. 17, pp. 305-314, 1963.

[6] W. Huang, D. Huo, Z. Yu et al., "Spawning, larval development and juvenile growth of the tropical sea cucumber Holothuria leucospilota," Aquaculture, vol. 488, pp. 22-29, 2018.

[7] C. Poh-Sze, "Fisheries, trade and utilization of sea cucumbers in Malaysia," FAO Fisheries Technical Paper, FAO, Rome, 2005.

[8] H. Eriksson and S. Clarke, "Chinese market responses to overexploitation of sharks and sea cucumbers," Biological Conservation, vol. 184, pp. 163-173, 2015. 
[9] A. Bennett and X. Basurto, "Local Institutional Responses to Global Market Pressures: The Sea Cucumber Trade in Yucatán, Mexico," World Development, vol. 102, pp. 57-70, 2018.

[10] J. Prescott, J. Riwu, A. P. Prasetyo, and N. Stacey, “The money side of livelihoods: Economics of an unregulated small-scale Indonesian sea cucumber fishery in the Timor Sea," Marine Policy, vol. 82, pp. 197-205, 2017.

[11] D. Meloni and G. Esposito, "Hygienic and commercial issues related to the illegal fishing and processing of sea cucumbers in the Mediterranean: A case study on over-exploitation in Italy between 2015 and 2017," Regional Studies in Marine Science, vol. 19, pp. 43-46, 2018.

[12] J. Prescott, C. Vogel, K. Pollock, S. Hyson, D. Oktaviani, and A. S. Panggabean, "Estimating sea cucumber abundance and exploitation rates using removal methods," Marine \& Freshwater Research, vol. 64, no. 7, pp. 599-608, 2013.

[13] R. Pangestuti and Z. Arifin, "Medicinal and health benefit effects of functional sea cucumbers," Journal of Traditional and Complementary Medicine, pp. 1-11, 2017.

[14] Sarawak Tourism Board, Kuching Visitor's Guide 2009-2010, 2009.

[15] A. Ceesay, M. N. Shamsudin, N. M. Alipiah, and I. S. Ismail, "Biodiversity and adaptability of Holothuria leucospilota and Stichopus japonicus sea cucumber species in artificial environment," Journal of Aquaculture Research \& Development, vol. 3, no. 2, 2012.

[16] C. Conand, "Holothurians," in FAO species identification guide. The marine living resources of the Western Central Pacific, $\mathrm{K}$. Carpenter and V. Niem, Eds., vol. 2, pp. 1157-1190, Food and Agriculture Organization, Rome, 1998.

[17] D. B. James, "Twenty sea cucumbers from seas around India," Naga, The ICLARM Quarterly, vol. 24, 2001.

[18] Dhargalkar. V. K. and D. Kavlekar, Seaweeds - A field manual, National Institute of Oceanography: Goa, 2004.

[19] A. J. Underwood, Experiments in ecology: their logical design and interpretation using analysis of variance, University Press: Cambridge, 1997.

[20] P. J. Somerfield, K. R. Clarke, and F. Olsgard, "A comparison of the power of categorical and correlational tests applied to community ecology data from gradient studies," Journal of Animal Ecology, vol. 71, no. 4, pp. 581-593, 2002.

[21] K. R. Clarke, R. N. Gorley, P. J. Somerfield, and R. M. Warwick, Change in Marine Communities: An Approach to Statistical Analysis and Interpretation, PRIMER-E Ltd, 3rd edition, 2014.

[22] G. J. Bakus, "The biology and ecology of tropical holothurians," in Biology and geology of coral reefs, O. A. Jones and R. Endean, Eds., pp. 325-367, Academic Press, New York, NY, USA, 1973.

[23] D. L. Pawson, The holothurian fauna of Cook strait, New Zealand, Zoology Publications: Victoria University of Wellington, 1963.

[24] S. W. Purcell, "Managing sea cucumber fisheries with an ecosystem approach," FAO: Fisheries and Aquaculture Technical Paper, FAO, Rome, Italy, 2010.

[25] FAO, Brief introduction to mariculture of five selected species in China, 2008, http://www.fao.org/docrep/field/003/AB736E/ AB736E00.htm. 


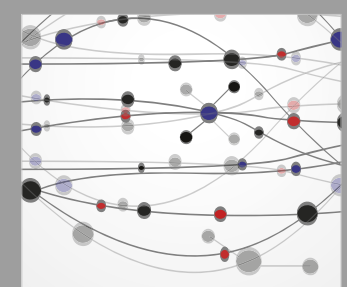

The Scientific World Journal
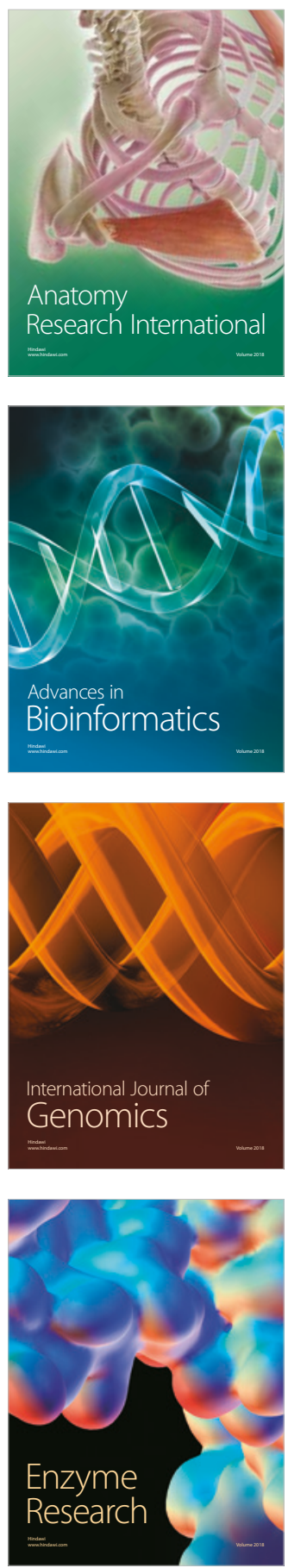
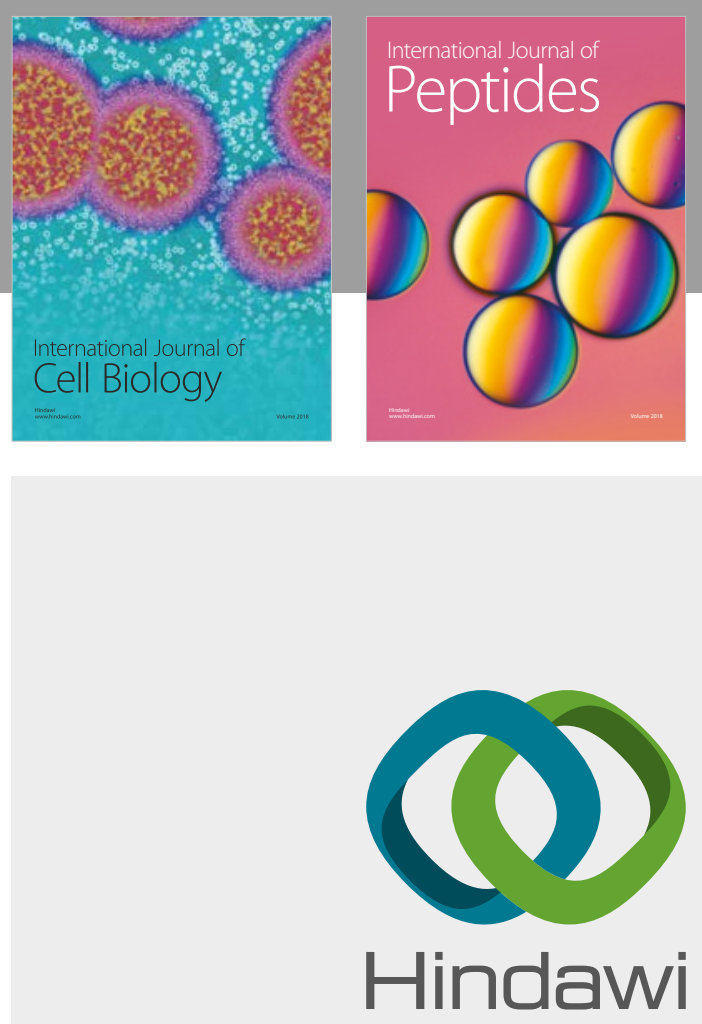

Submit your manuscripts at

www.hindawi.com
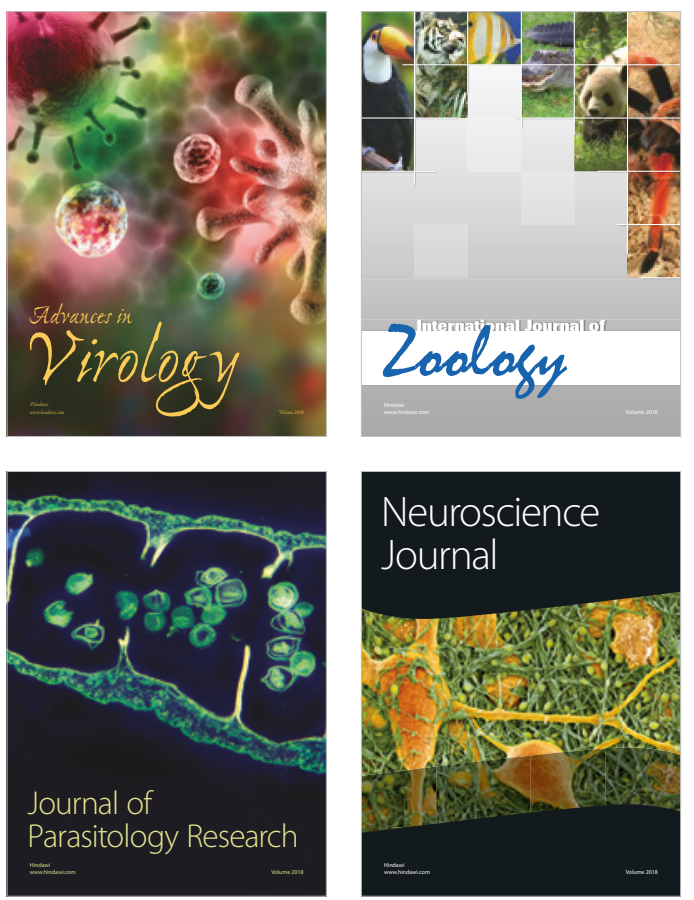
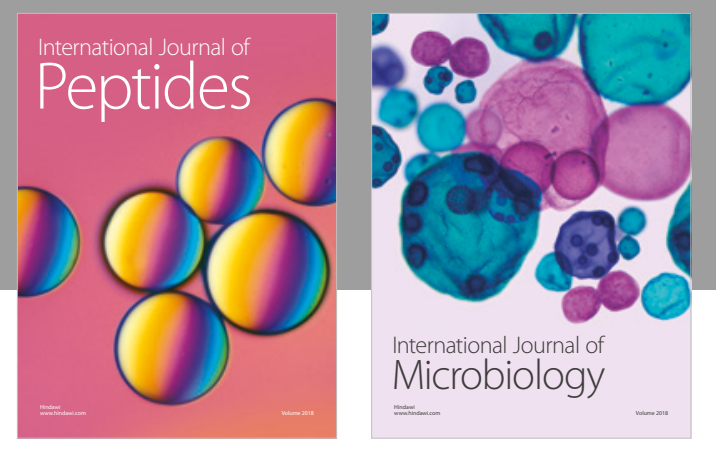

nternational Journal of Microbiology
Journal of
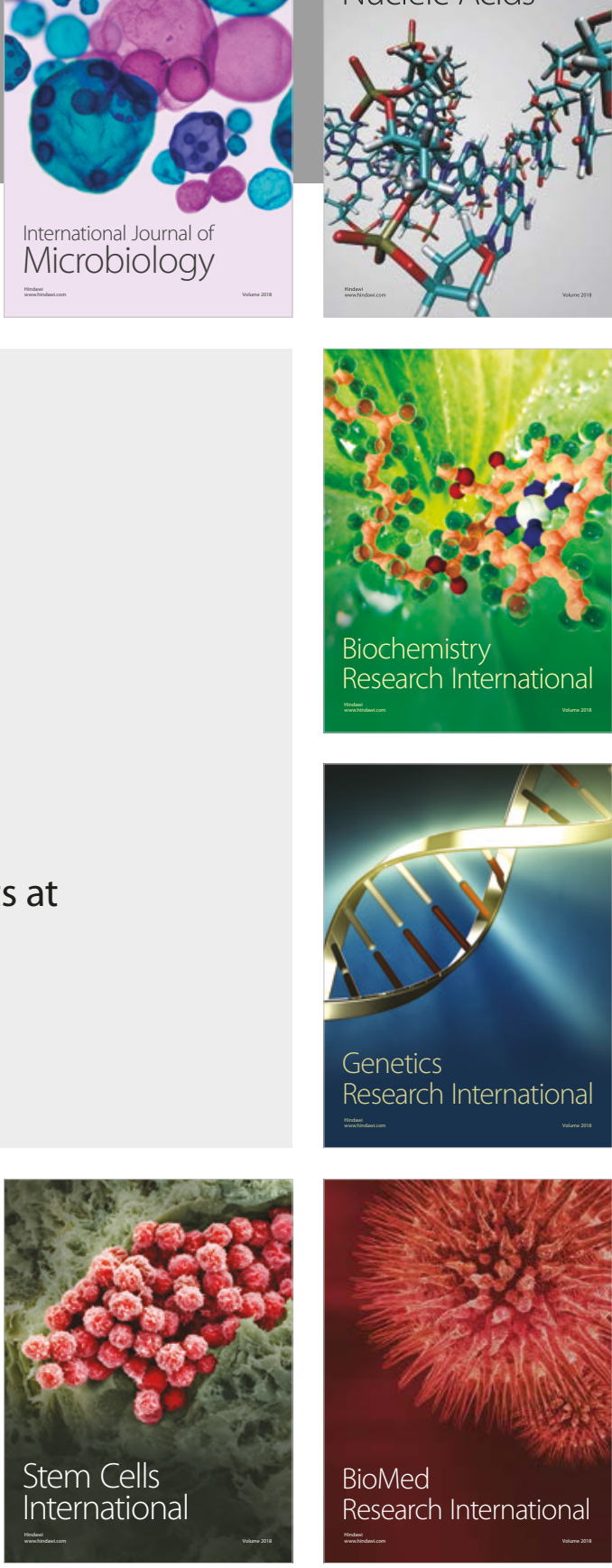
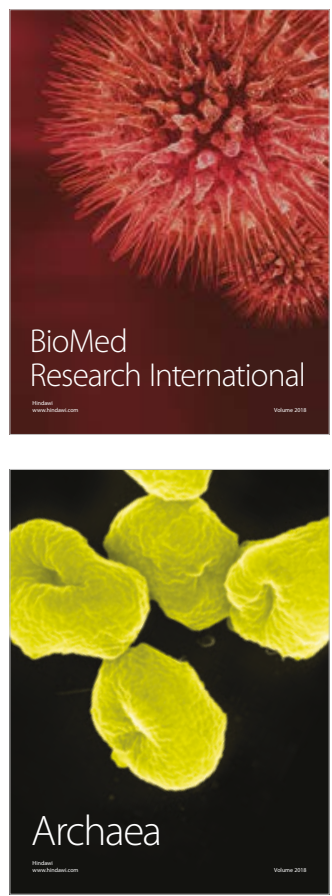